\title{
Perancangan Pembelajaran Bangun Ruang 3 Dimensi Berbasis Android
}

\author{
Imam Abdurrahman, Ucuk Darusalam, Benrahman \\ Fakultas Teknologi Komunikasi dan Informasi, Informatika, Universitas Nasional, Jakarta, Indonesia \\ E-mail: ${ }^{1}$ imam48322@gmail.com, ${ }^{2}$ ucuk.darusalam@gmail.com, ${ }^{3}$ ben.rahman@gmail.com
}

\begin{abstract}
Abstrak-Alat bantu mengajar untuk belajar Bangun Ruang sekarang masih bergantung pada cara lama, yaitu dengan cara masih menggunakan media 2 Dimensi. Tenaga pengajar seperti Guru masih mengalami kesulitan membuat alat visual untuk mempelajari materi Bangun Ruang 3 Dimensi. Dan Siswa masih saja merasakan kesulitan dalam mempelajari dan mendalami materi Bangun Ruang yang di sampaikan oleh tenaga pengajar tersebut, dengan keterbatasan dan kurang nya alat visual mereka hanya dapat membayangkan seperti apa bentuk Bangun Ruang tersebut. Dengan itu, penulis mencoba membuat aplikasi pembelajaran interaktif sehingga model-model geometris seperti kubus, tabung, kerucut, piramida dan bola ini dapat menumbuhkan minat dalam belajar matematika pada tingkat sekolah dasar (SD) dengan memanfaatkan teknologi Augmented Reality (AR), yaitu teknologi yang menggabungkan objek virtual dua dimensi atau tiga dimensi ke dalam sebuah lingkungan nyata dan kemudian memproyeksikan objek maya tersebut secara realtime. Salah satu materi dalam pembelajaran matematika untuk siswa kelas V sekolah dasar adalah Bangun Ruang. Bila memperhatikan tingkat usia rata-rata siswa Sekolah dasar pada kelas $\mathrm{V}$ adalah berada pada umur 10 - 11 tahun. Penulis memperoleh hasil akhir penelitian dalam bentuk pembelajaran Bangun Ruang 3 Dimensi dengan metode Virtual Button dan hasil uji dari perangkat Smartphone Xiaomi Redmi 4 dengan jarak minimal $\pm 15 \mathrm{~cm}$ dan maximal $\pm 81 \mathrm{~cm}$. Pengujian Kecepatan respon $<1$ detik maka Smartphone Xiaomi Redmi 4 menunjukkan hasil yang lebih baik dari Smartphone lainnya.
\end{abstract}

Kata Kunci: AR, Unity 3D, Bangun Ruang, Matematika, Unity

Abstract-Teaching aids for learning to Build Space now still depend on the old way, namely by still using 2-Dimensional media. Teachers such as Teachers still have difficulty making visual tools to learn the material of Building 3 Dimensions. And students still find it difficult to learn and explore the material to Build Space delivered by the teaching staff, with its limitations and lack of visual tools they can only imagine what the shape of the Space Build is like. With that, the author tries to make interactive learning applications so that geometric models such as cubes, tubes, cones, pyramids and balls can foster interest in learning mathematics at elementary school level by utilizing Augmented Reality (AR) technology, which is technology that merge two-dimensional or three-dimensional virtual objects into a real environment and then project these virtual objects in real time. One of the materials in learning mathematics for fifth grade elementary school students is Build Space. If you pay attention to the average age of elementary school students in class $V$ is at the age of 10-11 years. The author obtained the final results of the study in the form of learning to Build 3-Dimensional Space with the Virtual Button method and test results from Smartphone Xiaomi Redmi 4 devices with a minimum distance of $\pm 15 \mathrm{~cm}$ and a maximum of $\pm 81 \mathrm{~cm}$. Testing the response speed $<1$ second, the Xiaomi Redmi 4 Smartphone shows better results than other smartphones.

Keywords: AR, Unity 3D, Build Space, Mathematics, Unity

\section{PENDAHULUAN}

Bangun Ruang merupakan salah satu mata pelajaran matematika di Sekolah Dasar (SD). Saat belajar Bangun Ruang para siswa masih menggunakan media dalam bentuk papan tulis sehingga bagian dalam dan belakang bagian tidak dapat terlihat. Setiap jenis Bangun Ruang memiliki bentuk dan juga formula untuk luas dan volume masing-masing, sehingga banyak siswa yang tidak merasa tertarik untuk belajar tentang Bangun Ruang karena mereka merasa kesulitan dan tidak tahu persis bagaimana bentuk masing-masing Bangun Ruang tersebebut[1]. Menurut Piaget, tingkat pemikiran anak-anak usia sekolah dasar tetap konkret operasional, yang berarti bahwa untuk memahami konsep anak mereka masih harus diberikan kegiatan yang berkaitan dengan benda nyata atau peristiwa nyata yang dapat diterima oleh pikiran mereka[2].

Azuma (1997) mendefinisikan Augmented Reality sebagai kombinasi dari objek nyata dan virtual dalam lingkungan nyata, yang dieksekusi secara interaktif dalam waktu nyata, dan terdapat integrasi antara objek dalam tiga dimensi, yaitu objek virtual yang berintegrasi dengan dunia nyata. Benda-benda maya menampilkan informasi yang tidak dapat diterima oleh pengguna dengan inderanya sendiri. Oleh karena itu, Augmented Reality sesuai sebagai alat untuk membantu persepsi dan interaksi pengguna dengan dunia nyata. Informasi yang ditampilkan oleh benda maya membantu pengguna melaksanakan kegiatan-kegiatan dalam dunia nyata[3]. Marker augmented reality adalah jenis augmented reality yang mengenali marker dan mengidentifikasi pola marker ini untuk menambahkan objek virtual ke lingkungan nyata[4].

Virtual button merupakan tombol-tombol buatan berupa gambar yang dibuat pada layar atau monitor sebagai pengganti tombol sebenarnya. Virtual button dapat dibuat untuk dalam layar touchscreen sehingga penggunaannya hanya menekan tombol virtual tersebut dengan jari untuk menggunakannya. Sedangkan untuk layar biasa penggunaannya dengan cara meng-klik virtual button tersebut.

Beberapa peneliti pernah melakukan penelitian tentang Bangun Ruang 3D berbasis Augmented Reality (AR). Penelitian oleh Enang Rusnandi pengembangan media pembelajaran pemodelan Bangun Ruang 3D untuk Siswa Sekolah Dasar dengan metode Pengembangan Multimedia[1]. Penelitian oleh M. Irwan Ukkas (2018) merancang pembelajaran bangun ruang 3D berbasis Augmented Reality (AR), aplikasi Unity Engine dengan 
metode Marker Based Tracking[2]. Penelitian yang dilakukan oleh Aries Suharso (2012) merancang model pembelajaran interaktif untuk membangun ruang 3D berdasarkan Augmented Reality (AR) dan menggunakan Software ARToolkit, 3D Max sebagai pembuatan object[3]. Awang Harsa K melakukan penelitian pembelajaran ruang berdasarkan Augmented Reality dengan metode penanda Augmented Reality, dengan software ArtoolKit, Blender dan metode yang di gunakan marker Augmented Reality[4]. Penelitian selanjutnya dilakukan oleh Ariesta Kartika Sari (2018) pengembangan media pembelajaran bangun ruang berbasis Augmented Reality pada tingkat sekolah dasar dengan metode Model pengembangan model Kemp \& Dayton[5].

Penelitian yang dilakukan Agung Subagyo (2015) merancang pengenalan rumus bangun ruang matematika berbasis Augmented Reality, perangkat yang di gunakan sebuah SmartPhone, dan Software Blender, Unity Engine, dengan Vuforia sebagai database[6]. Kemudian penelitian oleh Ridwan Abdul Hanan (2018) yang merancang sistem desain bahan ajar berbasis Augmented Reality pada materi bangun ruang bidang datar, dengan metode penelitian kualitatif deskriptif. Software yang di gunakan Unity Engine, dan Vuforia sebagai database[7]. Penilitian oleh Krishna Huda Bagus P (2018) merancang sistem pengembangan media pembelajaran berbasis android menggunakan Augmented Reality pada materi bangun ruang sisi datar dengan metode Reseacrh and Development[8]. Penelitian yang dilakukan Ayu Ningtias yang merancang sistem media Augmented Reality berbasis android dalam materi bangun ruang sisi datar dengan Research and Development (R\&D)[9].

Berdasarkan penelitian yang sebelumnya dilakukan oleh beberapa peneliti, dapat diuraikan beberapa permasalahan dalam pembelajaran bangun ruang 3 dimensi. Diantaranya adalah proses pembelajaran yang masih di atas kertas atau papan tulis, kemudian penulis melakukan penelitian untuk merancang sistem pembelajaran interaktif menggunakan model yang menarik, praktis dan lebih canggih sebagai sarana Geometri interaktif untuk membangun ruang tiga dimensi untuk guru dan siswa sekolah dasar menggunakan teknologi Augmented Reality. Penggunaan alat teknologi Augmented Reality membantu memfasilitasi tugas guru dengan menyediakan bahanbahan Geometris untuk membangun ruang tiga dimensi. Penggunaan alat teknologi Augmented Reality akan menciptakan suasana baru yang lebih interaktif dalam pembelajaran Geometri.

\section{METODE PENELITIAN}

\subsection{Analisis Sistem}

Analisis sistem dapat didefinisikan sebagai rincian lengkap sistem dalam komponen-komponennya untuk mengidentifikasi dan mengevaluasi masalah. Analisis ini bertujuan untuk memperoleh pemahaman umum tentang sistem yang akan dilakukan berdasarkan kontribusi para pihak dan juga pengalaman para analis yang tertarik pada sistem.

Melakukan penelitian ini menggunakan aplikasi Unity 3D yang dapat menampilkan objek pada marker dengan bantuan Vuforia sebagai database untuk marker dan fungsi yang menyertainya untuk memutar objek. Penelitian ini dilakukan dalam 3 tahap.

1. Tahap pertama (Concept) adalah adalah analisis masalah yang terdiri dari studi literatur, dengan tujuan mempelajari dasar teoritis literatur sehubungan dengan Augmented Reality, Unity 3D dan Vuforia. Tahap analisis masalah terkait dengan proses bekerja dan memecahkan masalah yang dihadapi selama proses kemajuan penulisan ilmiah. Persyaratan yang diperlukan dalam penelitian diuraikan dalam penulisan ilmiah ini.

2. Tahap kedua (Design, Material Collecting, Asembelly) merencanakan pengembangan program. Fase desain dimulai dengan desain model objek dan desain marker.

3. Tahap ketiga (Testing, Distribution) adalah implementasi dari pembuatan program, mulai dari instalasi perangkat lunak yang diperlukan hingga program yang sudah selesai. Kemudian program diuji.

Penulis memanfaatkan metode Marker Based Tracking dengan mengembangkan menjadi metode Virtual Button. Sistem pada AR ini membutuhkan penanda (marker) berupa gambar yang dapat tracker untuk membentuk reality. Penanda gambar tersebutlah yang disebut dengan marker. Marker-Based AR memiliki ciri khas yakni menggunakan fitur kamera pada device untuk menganalisa marker yang tertangkap untuk menampilkan obyek virtual seperti gambar. Lalu penulis menambahkan tombol virtual pada layar GUI Smartphone agar pengguna dapat berinteraksi dengan object virtual tersebut.

Analisa kebutuhan non fungsional yaitu berupa perangkat keras dan perangkat lunak, diantaranya adalah:

1. Perangkat Keras (Hardware)

Hardware adalah semua bagian fisik komputer yang berfungsi untuk memberi masukan, mengolah dan menampilkan keluaran, dan digunakan oleh sistem untuk menjalankan perintah yang telah diprogramkan. Berikut merupakan perangkat keras (Hardware) yang digunakan penulis untuk membuat aplikasi pembelajaran bangun ruang 3 dimensi yaitu :
a. Laptop
b. Mouse
c. SmartPhone
d. Keyboard

2. Perangkat Lunak (Software) 


\section{JURNAL MEDIA INFORMATIKA BUDIDARMA}

Volume 4, Nomor 1, Januari 2020, Page 89-95

ISSN 2614-5278 (media cetak), ISSN 2548-8368 (media online)

Available Online at https://ejurnal.stmik-budidarma.ac.id/index.php/mib

DOI 10.30865/mib.v4i1.1894

Software merupakan beberapa perintah yang dieksekusi oleh mesin komputer dalam mengerjakannya. Secara luas perangkat lunak dapat diartikan sebagai suatu prosedur pengoprasian. Adapun perangkat lunak yang digunakan untuk pembuatan aplikasi interaktif ini adalah:
a. OS Windows 10 Pro 64-bit
b. Unity 2019.1.14f1
c. Adobe Photoshop CC 2015.5
d. Paint3D 6.1907.18017.0
e. Vuforia Engine 8.5
f. Android Build Support (SDK, NDK Tools, Open JDK)
g. Google Chrome Version 78.0.3904.108 (Official Build) (64-bit)

\subsection{Flowchart Perancangan Aplikasi}

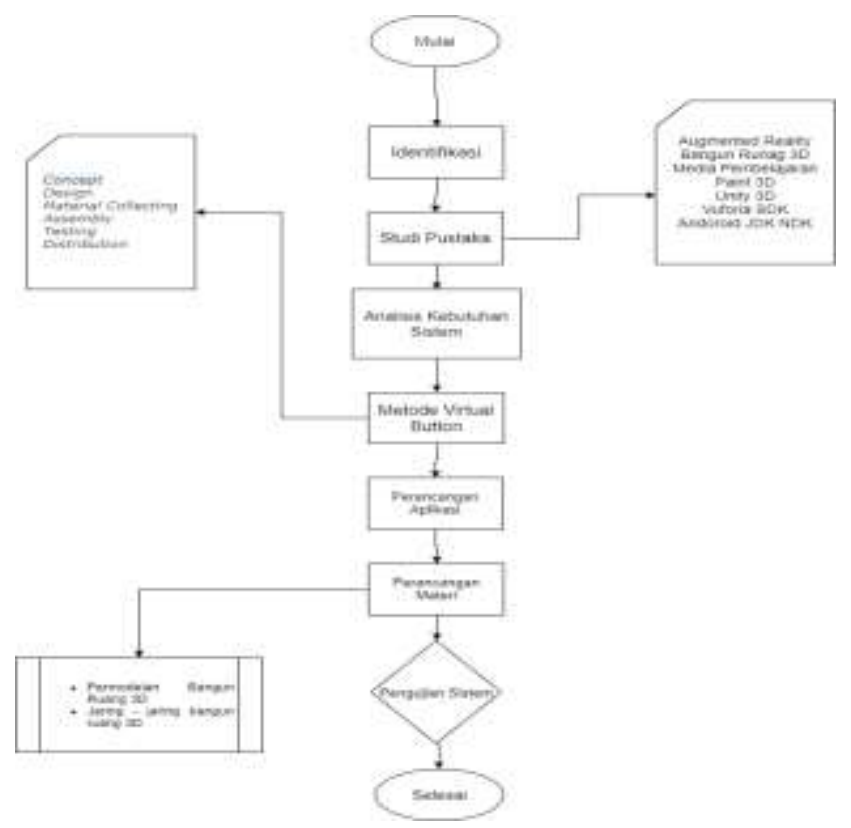

Gambar 1. Diagram Alir Penelitian (Flowchart)

Sumber: Pengolahan Data

1. Mulai

Berisi intruksi untuk persiapan peralatan yang di perlukan sebelum menangani pemecahan masalah.

2. Identifikasi

Identifikasi masalah adalah proses penelitian yang mungkin paling penting di antara proses lainnya. Pada tahap ini, penulis mencoba mengidentifikasi masalah yang ada. Tahap ini adalah tahap awal dalam persiapan penyelidikan ini. Hasil identifikasi ini menjadi latar belakang untuk merumuskan masalah yang akan diteliti. Masalah yang diidentifikasi adalah bagaimana merancang sarana pembelajaran untuk memodelkan bentuk tiga dimensi untuk siswa sekolah dasar menggunakan teknologi Augmented Reality.

3. Studi Pustaka

Tinjauan pustaka dilakukan untuk dilakukan untuk mendapatkan teori dasar yang diperlukan. Penulis mengemas materi dalam skema aplikasi yang nantinya akan menjadi aplikasi media pembelajaran yang menarik.

4. Analisa Spesifikasi Kebutuhan Sistem

Setelah data dikumpulkan, analisis ini dilakukan untuk menemukan apa yang diperlukan untuk merancang aplikasi media pembelajaran pada pemodelan bentuk tiga dimensi untuk siswa sekolah dasar melalui penggunaan teknologi Augmented Reality, sehingga Aplikasi yang dirancang dapat membuat aplikasi yang lebih menarik. dan metode pembelajaran interaktif.

5. Metode

Penulis menggunakan metode Virtual Button, lalu menentukan konsep mencari studi literatur tentang Bangun Ruang, Augmented Reality. Kemudian mendesain model objek dan desain marker. Setelah tahap $1-4$ selesai maka akan mengimplementasi dari pembuatan program, mulai dari instalasi perangkat lunak yang diperlukan hingga program yang sudah selesai. Kemudian program diuji.

Pada kesimpulan ini akan menjawab permasalahan yaitu dengan menggunakan metodologi pengembangan multimedia apakah lebih efektif dengan belajar dengan cara 3 dimensi pada anak usia 10 - 11 tahun atau tidak. Pada penelitian ini menggunakan software dan hardware yang ditujukan untuk melakukan simulasi perancangan jaringan dengan spesifikasi seperti pada tabel berikut 


\section{HASIL DAN PEMBAHASAN}

\subsection{Implementasi}

Hasil implementasi berdasarkan analisis dan perancangan adalah sebagai berikut:

1. Marker dalam Pembelajaran bangun ruang 3 dimensi berbasis Android.

Tabel 1. Gambar marker.

Marker bola merupakan Marker untuk menampilkan objek
bola 3 dimensi

2. Tampilan Мenu Utama

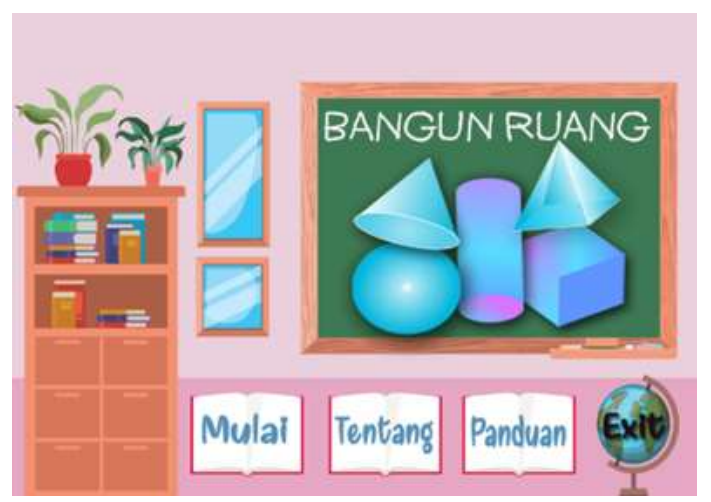

Gambar 2. Menu Utama

Sumber: Pengolahan Data

Menu utama memiliki 4 tombol yaitu tombol mulai tentang, panduan, dan tombol keluar. Tombol mulai berfungsi untuk memulai pemilihan bangun ruang. Tombol tentang bertujuan untuk melhat pembuat aplikasi dan mengunduh marker. Tombol panduan bertujuan untuk mengetahui panduan cara pemakaian aplikasi tersebut. Sedangkan tombol keluar berfungsi untuk keluar dari program. Seperti yang terlihat padaga gambar 4.

3. Visualisasi objek tiga dimensi untuk bangun ruang berdasarkan Augmented Reality.

Objek 3D memiliki ruang tampilan objek yang solid. Sebagai contoh penulis mencoba tracker marker dengan mengarahkan camera pada marker. Objek padat adalah visualisasi bentuk objek dalam ruang yang lengkap. Rumus yang berlaku untuk objek-objek ini ditampilkan dengan menekan tombol antarmuka pengguna rumus. Maka informasi tentang rumus bangun ruang tersebut akan muncul dalam bentuk gambar 5 dan 6 . 
JURNAL MEDIA INFORMATIKA BUDIDARMA

Volume 4, Nomor 1, Januari 2020, Page 89-95

ISSN 2614-5278 (media cetak), ISSN 2548-8368 (media online)

Available Online at https://ejurnal.stmik-budidarma.ac.id/index.php/mib DOI 10.30865/mib.v4i1.1894

Gambar 5 menunjukkan visualisasi gambar objek yang di scan oleh kamera Smartphone, objek 3D yang muncul berupa objek bangun ruang kubus yang berwarna biru.

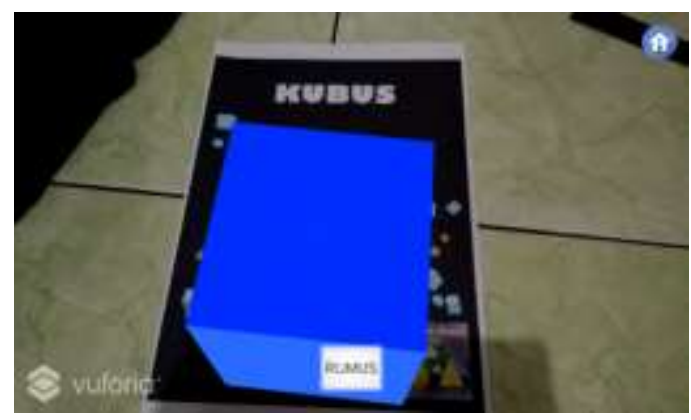

Sumber: Pengolahan Data

Gambar 3. Visualisasi objek kubus tiga dimensi

Rumus yang berlaku untuk objek-objek ini ditampilkan dengan menekan tombol antarmuka pengguna rumus. Maka informasi tentang rumus bangun ruang tersebut akan muncul dalam bentuk gambar 6 .

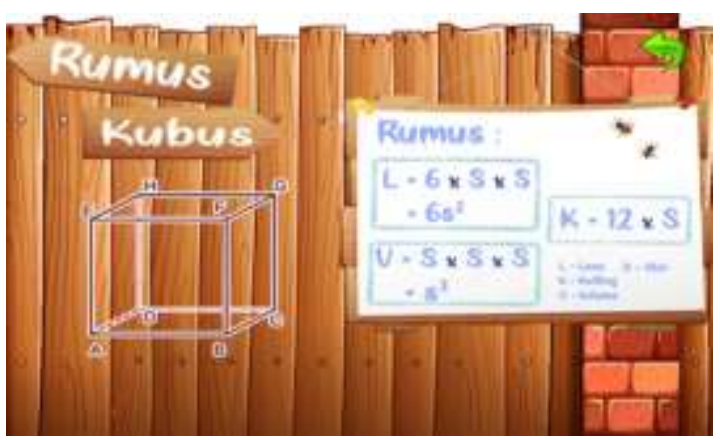

Gambar 4. Tampilan menu rumus kubus Sumber: Pengolahan Data

Pada gambar 7 menampilkan menu tentang yang berisi data pembuat dan marker aplikasi tersebut. Apabila pengguna belum mempunyai marker bisa mengunduh pada tombol Unduh Marker tersebut.

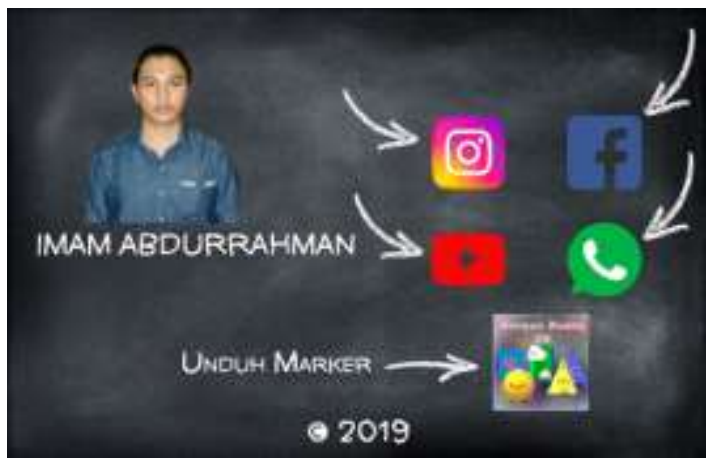

Gambar 5. Visualisasi menu panduan

Sumber : Pengolahan Data

Tabel 2 menunjukkan hasil pengujian tes pada beberapa perangkat Smartphone Android yang berbeda. Kriteria pengujian berisi tentang object 3d, suara, dan rotasi menunjukkan data keberhasilan yang sama pada setiap Smartphone.

Tabel 2. Pengujian Fitur Aplikasi pada perangkat Smartphone

\begin{tabular}{cccc}
\hline Perangkat & \multicolumn{3}{c}{ Kriteria Pengujian } \\
\cline { 2 - 4 } & Object 3D & Suara & Rotasi \\
\hline Xiaomi Redmi 4 & Berhasil & Berhasil & Berhasil \\
Xiaomi Mi Max & Berhasil & Berhasil & Berhasil \\
Xiaomi Redmi 4a & Berhasil & Berhasil & Berhasil \\
Samsung A5 & Berhasil & Berhasil & Berhasil \\
Realme 5 Pro & Berhasil & Berhasil & Berhasil \\
\hline
\end{tabular}




\section{Sumber: Pengolahan Data}

Tabel 3 menunjukkan hasil pengujian pada beberapa perangkat Smartphone Android berbeda, pada jarak minimal Smartphone Xiaomi Mi Max mendapatkan jarak minimal $\pm 13 \mathrm{~cm}$ pada Smartphone Xiaomi Redmi 4 mendapatkan jarak maximal $\pm 81 \mathrm{~cm}$.

Tabel 3. Pengujian jarak dan waktu tracking pada perangkat Smartphone

\begin{tabular}{ccc}
\hline Perangkat & \multicolumn{2}{c}{ Kriteria Pengujian } \\
\cline { 2 - 3 } & Jarak Min & Jarak Max \\
\hline Xiaomi Redmi 4 & $\pm 15 \mathrm{~cm}$ & $\pm 81 \mathrm{~cm}$ \\
Xiaomi Mi Max & $\pm 13 \mathrm{~cm}$ & $\pm 33 \mathrm{~cm}$ \\
Xiaomi Redmi 4a & $\pm 15 \mathrm{~cm}$ & $\pm 63 \mathrm{~cm}$ \\
\hline
\end{tabular}

Sumber: Pengolahan Data

Tabel 4 menunjukkan hasil pengujian pada beberapa perangkat Smartphone yang berbeda dengan cara memanfaatkan keadaan cahaya dengan intensitas 51\% - 100\% maka object akan langsung timbul pada ke tiga layar Smartphone tersebut.

Tabel 4. Pengujian tracking dengan intesitas cahaya pada perangkat Smartphone

\begin{tabular}{ccccc}
\hline Perangkat & \multicolumn{4}{c}{ Cahaya } \\
\cline { 2 - 4 } & $0-10 \%$ & $11-50 \%$ & $51-60 \%$ & $61-100 \%$ \\
\hline Xiaomi Redmi 4 & Tidak Merespon & Lama Merespon & Cepat Merespon & Cepat Merespon \\
Xiaomi Mi Max & Tidak Merespon & Lama Merespon & Cepat Merespon & Cepat Merespon \\
Xiaomi Redmi 4a & Tidak Merespon & Lama Merespon & Cepat Merespon & Cepat Merespon \\
\hline
\end{tabular}

Sumber: Pengolahan Data

Tabel 5 menunjukkan hasil pengujian waktu respon AR pada beberapa perangkat Smartphone. Perangkat Smartphone Xiaomi Redmi 4 menunjukkan waktu respon paling cepat dengan waktu 1 detik. Dan perangkat Smartphone yang paling lambat dengan waktu respon 5 detik adalah Xiaomi Redmi 4a.

Tabel 5. Kriteria pengujian jarak kecepatan respon pada perangkat Smartphone.

\begin{tabular}{cc}
\hline Perangkat & Waktu Respon \\
\hline Xiaomi Redmi 4 & $<1$ detik \\
Xiaomi Mi Max & $<7$ detik \\
Xiaomi Redmi 4a & $<5$ detik \\
\hline
\end{tabular}

Sumber: Pengolahan Data

\section{KESIMPULAN}

Berdasarkan uraian hasil diskusi, dapat disimpulkan bahwa pembelajaran membangun ruang augmented reality dengan metode pengembangan multimedia berbasis Android adalah sebagai berikut:

1. Membuat aplikasi pembelajaran pembuatan Augmented Reality tiga dimensi dengan metode Virtual Button berbasis Android menggunakan Unity 3D, Paint3D, Adobe Photoshop CC2015, Vuforia SDK dan GeoGebra Classic.

2. menggunakan marker ini dapat menjadi sarana alternatif atau sebagai alat bantu belajar Matematika.

3. Dengan pengujian pada Smartphone Android yang berbeda hasil uji menunjukkan perbedaan pada setiap perangkat.

4. Dengan jarak yang cukup dan pencahayaan yang baik maka marker yang di tracking oleh camera akan memunculkan object yang terlihat jelas.

5. Pada hasil pengujian Smartphone Xiaomi Redmi 4 menunjukkan hasil lebih baik dari Smarphone lain nya. Dari segi pengujian jarak tracking mendapatkan hasil minimal $\pm 15 \mathrm{~cm}$ dan maximal $\pm 81 \mathrm{~cm}$. Pengujian respon object mendapatkan waktu respon paling cepat $<1$ detik.

\section{REFERENCES}

[1] E. Rusnandi, H. Sujadi, and E. F. N. Fauzyah, "Implementasi Augmented Reality pada Pengembangan Media Pembelajaran Bangun Ruang 3D untuk Siswa Sekolah Dasar," Infotech J., vol. 1, no. 2, pp. 24-31, 2015.

[2] M. Irwan Ukkas, R. Andrea, and D. Deny, "Pembelajaran Bangun Ruang Augmented Reality Dengan," Sebatik Stmik Wicida, vol. 3, no. 2, pp. 12-18, 2018.

[3] A. Suharso, "Solusi, Vol. 11 No. 24 Edisi September-Nopember 2012 MODEL PEMBELAJARAN INTERAKTIF BANGUN RUANG 3D BERBASIS AUGMENTED REALITY Oleh : Aries Suharso," Model Pembelajaran Interaktif Bangun Ruang 3D Berbas. Augment. Real., vol. 11, no. 24, pp. 1-11, 2012. 


\section{JURNAL MEDIA INFORMATIKA BUDIDARMA}

Volume 4, Nomor 1, Januari 2020, Page 89-95

ISSN 2614-5278 (media cetak), ISSN 2548-8368 (media online)

Available Online at https://ejurnal.stmik-budidarma.ac.id/index.php/mib

DOI 10.30865/mib.v4i1.1894

[4] A. H. K, A. Y. R, and B. Satria, "Pembelajaran Bangun Ruang Berbasis Augmented Reality Dengan Metode Marker Augmented Reality," Sebatik Stmik Wicida, pp. 19-24, 1997.

[5] A. K. Sari, P. Dellia, M. Dicky, and C. Cholillah, "Pengembangan Media Pembelajaran Bangun Ruang Berbasis Augmented Reality pada Tingkat Sekolah Dasar," Pros. Semin. Nas. Pendidik. KALUNI, vol. 1, no. April, pp. 56-57, 2018, doi: 10.30998/prossnp.v1i0.15.

[6] A. Subagyo, T. Listyorini, and A. Susanto, "Pengenalan Rumus Bangun Ruang Matematika Berbasis Augmented Reality," Pros. SNATIF, vol. 2, no. 2, pp. 29-32, 2015.

[7] R. A. Hanan, I. Fajar, and S. A. Pramuditya, "Desain Bahan Ajar Berbasis Augmented Reality pada Materi Bangun Ruang Bidang Datar," Pros. SNMPM II, pp. 287-299, 2018.

[8] K. H. B. P, A. Buchori, and A. N. Aini, "Pengembangan Media Pembelajaran Berbasis Android Menggunakan Augmented Reality Pada Materi Bangun Ruang Sisi Datar,” J. Pendidik. Mat. dan Sains, vol. 6, no. 1, pp. 61-69, 2018.

[9] A. Ningtias, A. Hartoyo, and D. Suratman, "Media Augmented Reality Berbasis Android Dalam Materi Bangun Ruang Sisi Datar Siswa SMP," pp. 1-11, 2013. 